\title{
Relationship between gingival bleeding and blood glucose level: a case- control study
}

\author{
N. Sayeeganesh ${ }^{1}$, Basker PK ${ }^{2}$, Manovijay $\mathbf{B}^{3}$, Saranyan $\mathbf{R}^{4}$, N. Shanmugasundaram ${ }^{5}$, N Vijayakumar ${ }^{6}$ \\ ${ }^{1}$ Dr. N. Sayeeganesh, MDS, Professor, Department of Periodontia, VMS Dental College, Salem, Tamilanadu India, ${ }^{2}$ Dr. \\ P. K. Baskar MDS, Professor, Department of Periodontia, VMS Dental College, Salem, ${ }^{3}$ Dr. B. Manovijay, MDS, Senior \\ Lecturer, Department of Periodontia, VMS Dental College ${ }^{4}$ Dr. R. Saranyan, MDS, Professor, Department of \\ Periodontia, VMS Dental College, Salem, ${ }^{5}$ Dr. N. Shanmugasundaram, MDS, Peridontal Surgeon, ${ }^{6}$ Dr N Vijayakumar , \\ MDS, Reader, KSR, Institute of Dental Sciences and Research, Tiruchengode, India
}

Address for correspondence: Dr. B. Manovijay, drmanovijaymds@yahoo.com

\begin{abstract}
Aim: To correlate the percentage of gingival bleeding sites and blood glucose levels in diabetic and non-diabetic patients. Materials and methods: a total of hundred patients participated in this case-control study. They were grouped in to two groups. Group 1 consisted of 50 type II diabetic patients and group II consisted of 50 non-diabetic patients. Post prandial blood glucose levels oral-hygiene index and percentage of sites with bleeding on probing were recorded. The results obtained were analysed statistically using students ' $t$ ' test. Results: Bleeding tendencies were more in diabetic patients compared to non-diabetic patients.It was found to be highly statistically significant $(\mathrm{P}<0.01)$. Conclusion: The study suggested the association of gingival bleeding to the blood glucose level. Blood glucose level reflects their metabolic rates.
\end{abstract}

Keywords: Diabetes, Gingival Bleeding, Blood Glucose, Inflammation, Periodontitis.

\section{Introduction}

Oral cavity is the portal of entry for many microorganisms and hence it can be called as the index of the body. The oral -systemic relationship has been extensively studied by various researchers and periodontal medicine is emerging as a new field in the field of dentistry. The relationship between diabetes, a hypoglycemic state and periodontitis, a disease affecting the supporting structures of the teeth has been studied as early as 1960[1]. Recent studies have proved the fact that diabetes and periodontitis confound the systemic effects of one another. Chronic inflammation seems to be the common bridging factor between periodontitis and diabetes [2]. Gingival bleeding is a very strong active sign of gingival inflammation.Dental plaque remains the primary etiological factor for chronic gingivitis; however, anything that encourages plaque accumulation/retention will invariably aggravate existing gingivitis[3].The reason for increased bleeding in poorly controlled diabetics could be either inflammation or vascular changes in the gingiva [4].A

Manuscript received: $18^{\text {th }}$ May 2015

Reviewed: $4^{\text {th }}$ June 2015

Author Corrected: $14^{\text {th }}$ June 2015

Accepted for Publication: $29^{\text {th }}$ June 2015 hyper inflammatory gingival response may be the reason for increased gingival inflammation despite similar qualitative and quantitative bacterial plaque characteristics in diabetic patients [5]. In a study by Kaisa $M$ et al [6], they suggested that an increase in gingival bleeding in association with hyperglycemia was associated biological alterations. These alterations lower host resistance toward plaque. Considering the above facts, the study was conducted to correlate the percentage of gingival bleeding sites and blood glucose levels in diabetic and non-diabetic patients. The objective of the study is to diagnose periodontal disease with a systemic predisposition at an early stage and to stabilize diabetes mellitus before it predisposes to advanced periodontitis.

\section{Materials and Methods}

The study was conducted in the department of periodontics, Vinayaka Missions Sankrachariyar Dental college, Salem, Tamilnadu, India. A total of 100 patients were selected from the outpatient ward of the department of periodontics. The study was explained to the patients and an informed consent was obtained from 
them. Patients of both sexes with an age group of 30 to 75 years participated in this study. The study period was 3 months. They were divided into two groups. Group 1 consisted of 50 type II diabetic patients and group II consisted of 50 non diabetic patients. Both groups were having a minimum of 20 teeth in their oral cavity. They were of similar socio-economic status and were following similar oral hygiene habits. Frequency of brushing and methods of brushing were recorded. Patients using oral-hygiene aids other than toothbrush from childhood were excluded from the study. Oral hygiene index was recorded [7,8]. Patients were selected randomly, independent of their gender. Pregnant and lactating women, children, smokers, patients with systemic diseases other than diabetes, acute oral lesions and patients undertaking medication were excluded. Benedicts test was carried out to distinguish diabetic and non-diabetic patients. Post prandial blood glucose test (one hour after food) was done by O-Toludine method [9]. Aianomo and Bay [10] gingival bleeding index was used to calculate the percentage of sites positive of gingival bleeding. Gentle probing of gingival crevice around every tooth was carried out and appearance of bleeding within 10 seconds was recorded. The results thus obtained were recorded and analyzed statistically using students 't' test.

\section{Results}

In this study the gingival bleeding scores were compared between diabetics and non-diabetics. It was observed that bleeding tendencies of non-diabetics were with a maximum score of $60 \%$ where as in type II OR non-insulin dependent diabetes mellitus it was $100 \%$. The results were analyzed by students' $t$ ' test and it was found to be highly significant $(\mathrm{P}<0.01)$ as shown in table: 1

Table1: Gingival bleeding in diabetic and Non diabetic

\begin{tabular}{|l|l|l|l|l|}
\hline \multicolumn{1}{|c|}{ Groups } & \multicolumn{1}{|c|}{ Mean \pm SD } & Mean difference & Students t test & P value \\
\hline Diabetics & $59.3125 \pm 30.574$ & 33.2105 & 4.100 & $<0.01$ \\
\cline { 1 - 2 } Non-diabetics & $26.1020 \pm 15.6740$ & & & \\
\hline
\end{tabular}

Fig1: bar graph showing oral-hygiene status of group 1 and group 2 patients

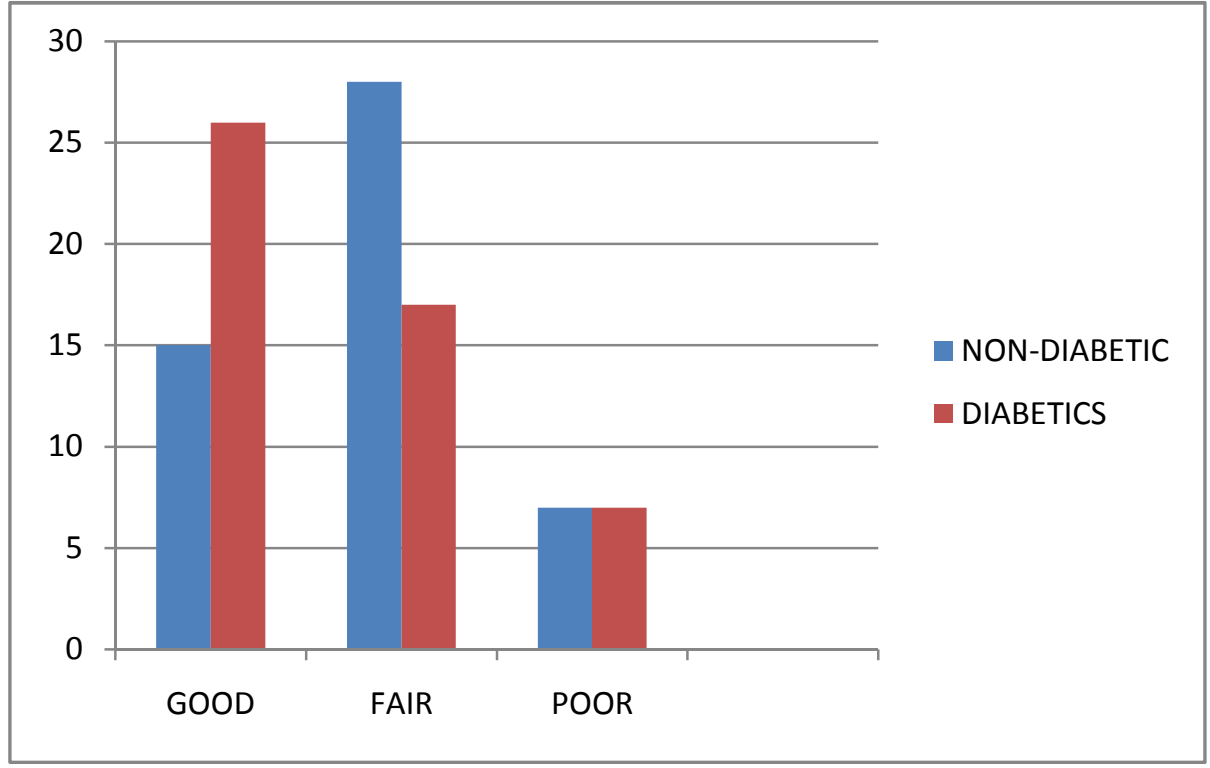


Fig 2: Line chart showing percentage of bleeding on Probing in both group

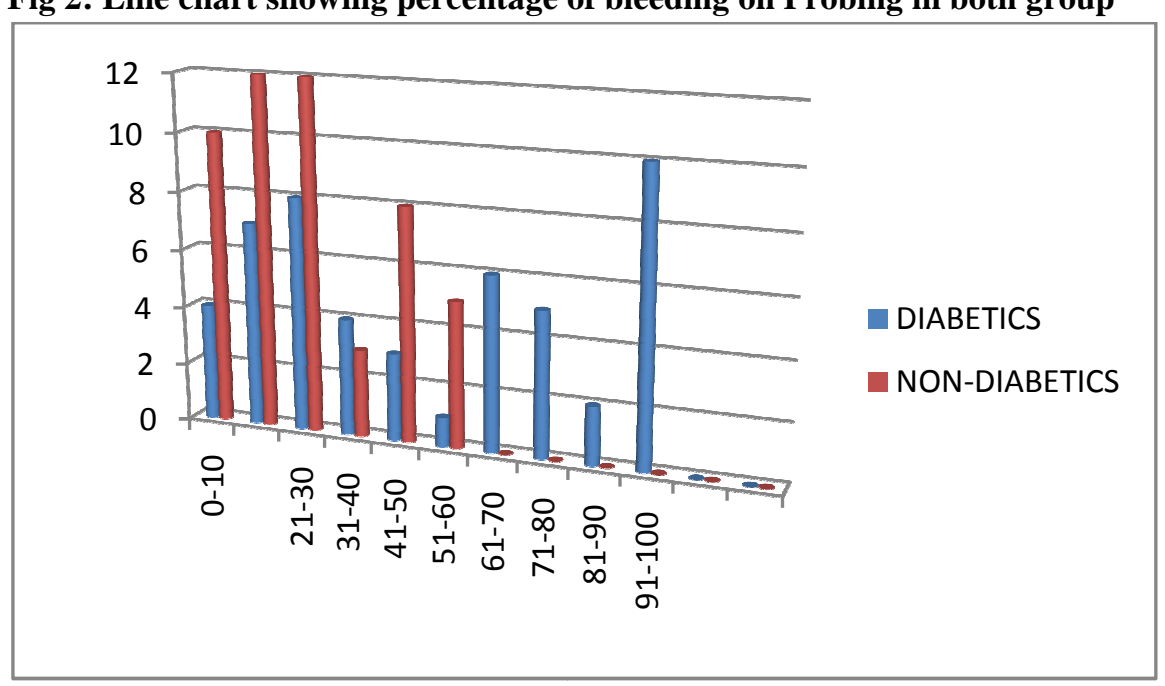

\section{Discussion}

Diabetes mellitus (DM) is a clinical syndrome characterized by hyperglycemia due to absolute or relative deficiency of insulin. It is broadly classified into two categories-Type I or insulin dependent diabetes and type II or non-insulin dependent diabetes. Deficiency of insulin leads to reduced rate of absorption of blood glucose from the peripheral tissues and an increased rate of mobilization of glucose from the liver into the peripheral circulation [11]. Gingival bleeding is a sign of gingival inflammation which is due to thinning out or micro ulceration of epithelial lining. It is one of the signs of active tissue destruction. Gingival bleeding is observed to increase with an increase in the blood glucose level. The blood glucose level in turn reflects the carbohydrate metabolic activity and thereby the severity of diabetes [12]. Metabolic alterations in the tissues may lower the resistance of diabetes to infection and thus influence the initiation, development and progression of periodontal disease. Impaired neutrophil function has been found in diabetic patients and may be another factor responsible for the decreased response to inflammation. The increased gingival bleeding indicates the presence of inflammation. Although gingival bleeding is considered as an indication for inflammation [13], it is also possible that vascular changes in DM may result in gingival bleeding.

In a study by Tchobroutsky [14], the degree of gingival bleeding was more in diabetics than non-diabetics. It was similar to our study results. Similar observations were made by Bernicketal [15]. Various researches have proposed different reasons for gingival bleeding in diabetic patients. According to Spiersterin [16] and Listgarden [17], thickening of basement membrane due to glycosylation of membrane protein will cause thickening of blood capillaries leading to impairment in the diffusion of oxygen to gingiva. Witzum et al[18], in his study observed excess production of growth factors and cytokine which play an important role in both micro and macro-vascular alterations. He also proposed that free oxygen radicals would cause tissue destruction directly and exaggerate the inflammation related tissue destruction. Increase glucose level in gingival crevicular fluid(Reutervinget al)[19] may result in altered plaque microflora causing an increase in gingival bleeding(Zambon et al)[20].defective neutrophil (Ramamurthy et al)[21] function with decreased chemotactic and phagocytic activity(Bagdade et al[22]) were seen in diabetic patients. This might increase gingival inflammation.Schmmidt et al [23] showed a failure of defense cell activity in diabetic patients.

Hyperglycemia either directly or through advanced glycosylation end products formation causes various structural and functional modifications of cells and tissue hemostasis leading to reduction in host resistance which is reflected in gingiva as increased bleeding even with mild provocation [24]. Hence the diabetics bleed more than the non-diabetics.

\section{Conclusion}

From the results of the present study, it can be concluded that patients who are more prone to systemic diseases like diabetes should always undergo periodontal screening to prevent advanced periodontal destruction at an early stage. Like general health 
instructions, oral hygiene instructions should be a routine protocol during general medical examination.

Funding: Nil

Conflict of interest: None initiated.

Permission from Institutional Research Board (IRB): Yes

\section{References}

1. Benveniste R, Bixler D, Conneally PM. Periodontal disease in diabetics. J Periodontol. 1967 JulAug;38(4):271-9.

2. Saito T, ShimazakiY. Metabolic disorders related to obesity and periodontal disease. Periodontol 2000. 2007;43:254-66.

3. Nwhator Solomon O. and Ayanbadejo Patricia O. Uncommon causes of gingivitis. Journal of Dentistry and Oral Hygiene 3.5 (2011): 65-68.

4. Ervasti T, Knuuttila M, Pohjamo L, Haukipuro K. Relation between control of diabetes and gingival bleeding. J Periodontol. 1985 Mar;56(3):154-7.

5. Salvi GE, Kandylaki M, Troendle A, Persson GR, Lang NP. Experimental gingivitis in type 1 diabetics: a controlled clinical andmicrobiological study. J Clin Periodontol 2005;32(3):310-6

6. Karjalainen KM, Knuuttila ML. The onset of diabetes and poor metabolic control increases gingival bleeding in children and adolescents with insulindependent diabetes mellitus. J Clin Periodontol. 1996 Dec;23(12):1060-7.

7. Greene, John G. et al.The Simplified Oral Hygiene Index. The Journal of the American Dental Association, Volume 68, Issue 1, 7 - 13.

8. Soben Peter. Essentials of Preventive and Community Dentistry.firstedition; April 1999 (C) Arya publishers.

9. Caraway WT,WattsNB.Carbohydrates. In Tietz NW, Ed. Textbook of clinical chemistry, Philadelphia; $@$ WB Saunders, 1986; 775-828.

10. Armitage GC. The complete periodontal examination. Periodontol 2000. 2004;34:22-33.
11. D Antonia JA, Ellis D, Doft BH, Beckeradj, Drash AL, Kuller LH \& Orchard TJ: Diabetes complications and glycemic control. The Pittsburgh prospective insulin-dependent diabetes cohort study status report after 5 year of IDDM. Diabetes care; 12:694-700.

12. Ervasti T, Knuuttila M, Pohjamao L. Haukipuro. Relation between control of diabetes and gingival bleeding. J Periodontol. 1985 Mar;56(3):154-7.

13. Fahey TJ, Sadaty A, Jones WG, Barber A, Smoller B, Shires GT. Diabetes impairs the late inflammatory response to wound healing. J Surg Res. 1991 Apr;50(4):308-13.

14. Tchobroutsky G. Relation of diabetic control to development of microvascular complications. Diabetologia. 1978 Sep;15(3):143-52.

15. Bernick, SM, Cohen DW, Baker L, Laster L. Dental disease in children with diabetes mellitus. J Periodontol. 1975 Apr;46(4):241-5.

16. Spierstein MD, Raskin $\mathrm{P}$ and Burns $\mathrm{H}$ : Electron microscopic quantification of diabetic microangiopathy. Diabetes. 1973 Jul;22(7):514-27.

17. Listgarden M, Ricker E, Laster L, Shapiro J \& Cohen D. Vasular basement thickness in the normal and inflamed gingiva of diabetics and non-diabetics. J Periodontol. 1974 Sep;45(9):676-84.

18. Witztum JL. Role of modified lipoproteins in diabetic macroangiopathy. Diabetes 1997:46(supp 2):S112-S114.

19. Reuterving $\mathrm{CO}^{1}$, Reuterving G, Hägg E, Ericson T. Salivary flow rate and salivary glucose concentration in patients with diabetes mellitus.Influence of severity of diabetes. Diabete Metab. 1987 Jul-Aug;13(4):457-62.

20. Zambon J, Reynolds H, Fischer J.Shlossmem M, Dunford R \&Genco RJ: Microbiological and immunological studies of adult periodontitis in patients with non-insulin diabetic mellitis. J Periodontol. 1988 Jan;59(1):23-31.

21. Ramamurthy NS, Golub LM. Diabetes increases collagenase activity in extracts of rat gingiva and skin J Periodontal Res. 1983 Jan;18(1):23-30. 
22. Bagdade JD, Nielson KL, Bulger RJ. Reversible abnormalities in phagocytic function in poorly controlled diabetic patients. Am J Med Sci. 1972 Jun;263(6):451-6.

23. Schmidt AM, Hori O, Brett J, Yan SD, Wautier J-L \& Stern D. Cellular receptors for advanced glycation end products. Implications for induction of oxidatant stress and cellular dysfunction in the pathogenesis of vascular lesions. Arterioscler Thromb; 1994; 14:1521 1528.

24.

Taylor GW ${ }^{1}$, Burt BA, Becker MP, Genco RJ, Shlossm an M, Knowler WC, Pettitt DJ. Pettitt.Severe periodontitis and risk for poor glycemic control in patients with non-insulin-dependent diabetes mellitus J Periodontol. 1996 Oct;67(10 Suppl):1085-93.

\section{How to cite this article?}

N. Sayeeganesh, Basker PK, Manovijay B, Saranyan R, N. Shanmugasundaram, N Vijayakumar. Relationship between gingival bleeding and blood glucose level: a case-control study. Int J Med Res Rev 2015;3(6):588-592. doi: 10.17511/ijmrr.2015.i6.111. 